logos_i_ethos_1_(32)_2012,s. 273-278

Ewelina Topolska

\title{
Wokół Bułgakowskiej filozofii wszechjedności
}

\author{
Lilianna Kiejzik, Sergiusza Bułgakowa filozofia \\ wszechjedności, Filozofia Rosyjska, t. 1, Wydawnictwo \\ Naukowe Scholar, Warszawa 2010, ss. 282.
}

W 2010 r. ukazała się monografia Lilianny Kiejzik zatytułowana Sergiusza Bułgakowa filozofia wszechjedności. Książka jest kolejną z licznych publikacji Autorki poświęconych filozofii rosyjskiej, wśród których są również przekłady z języka rosyjskiego na polski. L. Kiejzik pracuje obecnie na stanowisku profesora nadzwyczajnego w Instytucie Filozofii Uniwersytetu Zielonogórskiego. W kręgu zainteresowań Badaczki znalazła się między innymi twórczość Włodzimierza Sołowjowa, Sergiusza Bułgakowa, Aleksego Łosiewa i innych rosyjskich myślicieli. Zredagowała między innymi dwutomową antologię pt. Niemarksistowska filozofia rosyjska. Antologia tekstów filozoficznych XIX i pierwszej połowy XX wieku (Łódź 2001-2002), jest także współredaktorką przewodnika po literaturze rosyjskiej, Polskie badania filozofii rosyjskiej (Warszawa 2009) oraz pracy zbiorowej zatytułowanej $\mathrm{Pa}$ lamas. Bułgakow. Łosiew. Rozważania o religii, Imieniu Bożym, tragedii filozofii, wojnie i prawach człowieka. Ostatnia ze wspomnianych pozycji ukazała się w ramach utworzonej przez L. Kiejzik serii książkowej Filozofia Rosyjska, w której opublikowany został również recenzowany tom. W przygotowaniu jest obecnie trzeci tom pod redakcją L. Kiejzik, E. Tacho-Godi, J. Uglika, Aleksy Łosiew, czyli rzecz o tytanizmie XX wieku. 
Celem serii jest publikowanie prac polskich badaczy zajmujących się szeroko rozumianą myślą i filozofią rosyjską XIX i XX w. Co więcej, Lilianna Kiejzik wraz z Jackiem Uglikiem prowadzi serwis internetowy Filozofia Rosyjska www.filozofiarosyjska.uz.zgora.pl, założony przy Instytucie Filozofii Uniwersytetu Zielonogórskiego, propagujący współczesne badania nad myślą rosyjską i - co ważniejsze - udostępniający publikacje na temat filozofii rosyjskiej w formie elektronicznej.

Jak wskazuje Autorka recenzowanej pracy, po śmierci S. Bułgakowa ukazało się stosunkowo niewiele monografii poświęconych jego osobie i twórczości. Wspomnijmy za Badaczką, że prócz fundamentalnego składającego się z dwóch tomów dzieła L. Zandera zatytułowanego Bog i mir (Mirosozercanije otca Sergiusza Bułgakowa), które ukazało się w 1948 r. w Paryżu, w samej Rosji ogłoszono drukiem prace: E. I. Chochłowa, Czełowiek i kultura w tworczestwie S. N. Bułgakowa, Orioł 1999; D. A. Kryłowa, Jewcharisticzeskaja czasza. Sofijne naczała, Czita 2000; J. Kazimirczak-Połonskajej, Profiessor protojeriej Sergij Bułgakow (1871-1944), Moskwa 2003; M. R. Elojana, S. N. Bułgakow: prawosławije i kapitalizm (fiłosofija choziajstwa), Rostów nad Donem 2004. W Polsce natomiast badaczami omawiającymi myśl filozoficzną tego rosyjskiego teologa i filozofa są między innymi: Andrzej Walicki, inicjator badań nad szeroko rozumianą myślą i filozofią rosyjską, Janusz Dobieszewski, ks. Henryk Paprocki, Michał Bohun, Jan Krasicki i Leszek Augustyn. Należy przy tym jednak zauważyć, że na polskim rynku wydawniczym nie ukazała się, aż do teraz, monografia, w której możemy odnaleźć tak skrupulatny opis życia Bułgakowa i formowania się jego filozofii wszechjedności. Można powiedzieć, że publikacja stanowi swoiste novum, gdyż wprowadza czytelnika w niezbadaną wcześniej problematykę. Trzeba przyznać - co jest jednym z wielu walorów książki - że Autorka zadała sobie wiele trudu, aby omówić temat w sposób wyczerpujący. Świadczy o tym fakt, że literatura (przede wszystkim materiały archiwalne), którą przytacza Badaczka, częściowo nie była wcześniej publikowana bądź nie została jeszcze przetłumaczona na język polski.

Omawiana monografia została napisana jasnym i przystępnym językiem, dzięki czemu nawet czytelnik, który nie miał wcześniej styczności 
z filozofią rosyjską, będzie w stanie zrozumieć jej specyfikę. Na uznanie zasługuje także formalna strona książki: spis treści ułożony jest poprawnie i przejrzyście, dołączona jest bibliografia oraz indeks osobowy i indeks pojęć, rzetelnie opracowane są również przypisy. Sama książka została wydana bardzo estetycznie, zawiera między innymi czarno-białe i kolorowe reprodukcje oraz fotografie głównego bohatera i patriarchów rosyjskich, obecnych pracowników Instytutu Teologii Prawosławnej św. Sergiusza w Paryżu, a także archiwalne zdjęcie, na którym widnieje list profesorów broniących Bułgakowa przed zarzutami o herezję.

Ogólnie mówiąc, monografia L. Kiejzik poświęcona jest filozofii wszechjedności w ujęciu rosyjskiego filozofa i teologa, Sergiusza Bułgakowa (1871-1944). Filozofia ta została ukazana przez Autorkę w wielu kontekstach i wątkach.

Bułgakow urodził się w Rosji w miasteczku Liwny w rodzinie prawosławnego duchownego. Jest autorem licznych publikacji z zakresu teologii, filozofii i ekonomii, które ukazywały się nie tylko w Rosji, ale i poza jej granicami. Za głoszone przez siebie poglądy - podobnie jak inni przedstawiciele rosyjskiego renesansu religijnego - został zmuszony do opuszczenia swego rodzinnego kraju, co nastąpiło w 1922 r. Uważa się go za jednego z przedstawicieli srebrnego wieku rozwoju intelektualnego w Rosji. Termin ten ukuty został przez rosyjskiego emigranta, krytyka literackiego Mikołaja Ocupa.

Recenzowana monografia składa się z czterech części, poprzedzonych wstępem. Część pierwsza „Życie i dzieło” - jak wskazuje tytuł - została poświęcona biografii Bułgakowa. Autorka przedstawia w niej nie tylko postać i życie rosyjskiego filozofa, ale i ogólny zarys formowania i ewolucji jego poglądów. W interesujący sposób omówione zostały problemy, z jakimi borykał się rosyjski myśliciel, gdy zaczął podążać drogą utorowaną już wcześniej przez Włodzimierza Sołowjowa, który „wypracował i wprowadził do języka filozofii rosyjskiej pojęcie «pozytywnej wszechjedności»" (s. 65). Jednakże w kwestii tej nie panuje jednomyślność. Jak wskazuje Autorka, niektórzy badacze twierdzą bowiem, że Bułgakow jedynie na początku swej drogi intelektualnej rozwijał filozofię wszechjedności, lecz później zaczął od niej odchodzić, tworząc 
własne ujęcie metafizyki; inni, na przykład Wasyl Zienkowski i Andrzej Walicki, sądzą, że jego koncepcja ewoluowała i była kontynuacją filozofii Sołowjowowskiej (por. s. 13-14).

Z filozofią wszechjedności wiąże się jeszcze inna problematyczna kwestia, mianowicie: „problem wolności interpretacyjnej w teologii” (s. 14). L. Kiejzik pisze, że Bułgakow, głosząc swe poglądy na temat filozofii wszechjedności (w jej aspekcie sofiologicznym), wzbudził wiele kontrowersji wśród ówczesnego duchowieństwa prawosławnego i niektórych myślicieli (np. teologa Włodzimierza Łosskiego). Warto zauważyć, że osobliwa sytuacja, w jakiej znalazł się wówczas rosyjski myśliciel (niejednokrotnie musiał znosić wręcz zjadliwą krytykę, przed którą mimo wszystko się nie ugiął), przypomina tę, w jakiej znalazł się przed nim Sołowjow. Obaj myśliciele, głosząc swe poglądy na temat Sofii - Mądrości Bożej, zostali oskarżeni o herezję. Jednakże w przypadku Bułgakowa w ostatecznym rozrachunku oskarżenia wycofano. Poproszono go, aby koncepcję tę jaśniej wyraził $\mathrm{i}$ „w swych wykładach z teologii dogmatycznej nie wspominał o sofiologii" (s. 234).

Zanim jednak Bułgakow zaczął rozwijać filozofię wszechjedności, przeszedł w młodości - podobnie jak niektórzy myśliciele rosyjscy (w tym Sołowjow) - swoisty kryzys wiary, który wpłynął na zmianę jego wyborów życiowych, a co za tym idzie, na zmianę światopoglądową: zamiast wstąpić do seminarium, a potem do Akademii Duchownej, wybrał Wydział Prawa Uniwersytetu Moskiewskiego, na którym studiował ekonomię polityczną. W okresie tym był ateistą, zafascynowanym marksizmem, jednakże z biegiem czasu zmienił swe poglądy i z zagorzałego materialisty stał się idealistą, który powrócił do korzeni, czyli do prawosławia. Warto w tym kontekście przytoczyć niezwykle wymowną wypowiedź Paula Evdokimova, który stwierdził, że „słyszy się często o maksymalizmie rosyjskiej duszy. Jest pewne, że utrata wiary pociąga za sobą skrajny nihilizm. Rosjanin jest z Bogiem, lecz nigdy bez Boga".

W części drugiej i trzeciej omawiane są dwa aspekty filozofii wszechjedności: diachroniczny i synchroniczny. W części drugiej, zatytułowanej „Wszechjedność w jej aspekcie diachronicznym”, Autorka rozpoczyna swe rozważania od uzasadnienia tezy, że idea wszechjedności nie 
jest pojęciem swoiście rosyjskim, lecz pojawiła się już w filozofii starożytnej i w średniowiecznej gnozie (por. s. 57-61), a także na gruncie późniejszej filozofii zachodniej (głównie niemieckiego idealizmu) (por. s. 61-62). Dopiero później przejęli ją myśliciele rosyjscy (np. słowianofile) (por. s. 65). Należy dodać, że choć idea ta wywodzi się ze starożytności, to na płaszczyźnie filozofii rosyjskiej została ona przedstawiona w nowym świetle.

W dalszej części rozważań L. Kiejzik dowodzi, że Bułgakow inspirował się wypracowanym przez Sołowjowa pojęciem wszechjedności. Jednakże ujęcie Bułgakowa jest nieco inne. Różnica pomiędzy tymi filozofami przejawia się w tym, że Bułgakow „uchronił” swą koncepcję przed popadnięciem w panteizm. Jak wskazuje Badaczka, ustanowił on „nieprzekraczalną, transcendentną przepaść oddzielającą Absolut od tego, co względne, Stwórcę od stworzenia. A u podstaw tej przepaści czy granicy leżała inna niż u Sołowjowa teoria idei zakładająca samodzielność i świata, i Absolutu” (s. 84). Ujęcie to stało się przyczynkiem stworzenia „prawosławnej koncepcji Sofii, [...] wzbogacającej symbolikę wszechjedności” (tamże). Ponadto L. Kiejzik przedstawia w ogólnym zarysie twórczość braci Sergiusza i Eugeniusza Trubieckich („zależnych” ideowo od Sołowjowa). W twórczości tej możemy odnaleźć jednak jedynie „kontur” idei wszechjedności (por. s. 84-87). Prócz tego, Badaczka rekonstruuje proces kształtowania się wspomnianej idei, a także jej „elementy składowe": sofiologię, kosmologię, antropologię i Bogoczłowieczeństwo. Wskazuje również, że Bułgakow znajdował się pod wpływem koncepcji wszechjedności, rozwijanej przez ojca Pawła Florenskiego.

W części trzeciej - „Wszechjedność w jej aspekcie synchronicznym" - idea wszechjedności zostaje rozpatrzona w dwóch kontekstach: filozoficznym i teologicznym. Autorka nie omieszkała też przedstawić jej dalszych kontynuacji w ujęciu Siemiona Franka, Lwa Karsawina, Mikołaja Łosskiego, Pawła Florenskiego i Aleksego Łosiewa.

Natomiast w części czwartej Autorka omówiła relacje Bułgakowa z ówczesnymi myślicielami - Mikołajem Bierdiajewem, Wasylem Rozanowem, ojcem Pawłem Florenskim oraz patriarchą Tichonem, a także wspomnienia mu współczesnych: współpracowników z Instytutu 
Teologii Prawosławnej św. Sergiusza w Paryżu, przyjaciół: Matki Marii (Skobcowej), Julii Reitlinger i innych.

Książka ta - wnikliwe i rzetelnie opracowane studium Bułgakowowskiej filozofii wszechjedności - jest godna polecenia szerokiemu gronu czytelników. Jest adresowana nie tylko do specjalistów zajmujących się filozofią rosyjską lub studentów, nie tylko do tych, których ujmuje specyfika myśli rosyjskiej, i nie tylko wierzących, ale także - może przede wszystkim - do każdego, kto pragnie zgłębić problematykę i źródła szeroko rozumianej myśli chrześcijańskiej. 